\title{
Size and structure of the Mediterranean medicinal leech, Hirudo verbana populations inhabiting wetlands around Lake Eğirdir, Turkey
}

\section{Eğirdir Gölü (Türkiye) çevresindeki sulak alanlarda yaşayan Akdeniz tıbbi süllüğü, Hirudo verbana popüllasyonlarının büyüiklüğü ve yapısı}

\author{
Mustafa Ceylan ${ }^{1,2 *}$ • Osman Çetinkaya ${ }^{2}$ \\ ${ }^{1}$ Medicinal Leech Application and Research Center, Isparta University of Applied Sciences, Isparta, Turkey \\ 2 Department of Basic Science, Faculty of Eğirdir Fisheries, Isparta University of Applied Sciences, Isparta, Turkey \\ iD https://orcid.org/0000-0002-3283-0637 \\ (D) https://orcid.org/0000-0001-6085-0128
}

\section{How to cite this paper:}

Ceylan, M. \& Çetinkaya, O. (2021). Size and structure of the Mediterranean medicinal leech, Hirudo verbana populations inhabiting wetlands around Lake Eğirdir, Turkey. Ege Journal of Fisheries and Aquatic Sciences, 38(4), 437-447. DOI: 10.12714/egejfas.38.4.05

Abstract: In the present study size and structure of the Mediterranean medicinal leech (Hirudo verbana Carena, 1820) populations inhabiting wetlands around Lake Eğirdir (Turkey) were investigated. Population size was estimated by removal methods, age classes were estimated for the first time in leeches (Hirudinea) using "Modal Progression Analysis" of body length frequencies using Bhattacharya's method. The population size and biomass of medicinal leeches around Lake Eğirdir were estimated to be 1,562,696 $\pm 805,613$ leeches and $467.26 \pm 172.91 \mathrm{~kg}$, respectively. Three age classes were identified; the age group of $0+$ was dominant with $78.6 \%$. While $89.9 \%$ of the individuals weighed less than $1 \mathrm{~g}$, whereas the broodstock was estimated to represent only $7 \%$. Body weight, body length and condition factor were found to be $0.52 \pm 1.19 \mathrm{~g}, 4.5 \pm 2.4 \mathrm{~cm}$ and $0.620 \pm 0.123$, respectively. This study reveals that the population size of $H$. verbana in the wetlands around Lake Eğirdir is relatively well preserved and there is no significant threat to the sustainability of the exploitation of the medicinal leech populations. It is concluded that the stability of the lake's water budget, the variety and abundance of the host in the undamaged wetlands, the socioeconomic structure of the leech collectors, the sales policies, and the effective activities of conservation and control units might affect conservation status of the medicinal leech populations inhabiting wetlands around Lake Eğirdir.

Keywords: Removal methods, Bhattacharya's method, body length frequency, sustainable management, conservation

Öz: Bu çalışma ile Eğirdir Gölü çevresindeki sulak alanlarında yaşayan Akdeniz tıbbi sülüğü (Hirudo verbana Carena, 1820) popülasyonlarının büyüklüğü ve yapısının araştıııması amaçlanmıştır. Popülasyon büyüklüğ̈̈ ürün azaltmaya dayalı metotlarla, yaş sınıfları ise sülüklerde (Hirudinea) ilk kez vücut boyu sınıfı frekansları kullanılarak Bhattacharya'nın "Modal Progression Analysis" metodu ile belirlenmiştir. Popülasyon büyüklüğü sırasıyla 1.562.696 \pm 805.613 adet ve 467,26 $\pm 172,91 \mathrm{~kg}$ olarak belirlenmiş̧tir. Üç farklı yaş sınıfı tespit edilmiş; $0+$ yaş grubunun $\% 78,6$ ile baskın grup olduğu belirlenmiştir. 1 g'dan küçük bireylerin popülasyonun \%89,9'unu temsil ettiği, buna karşın anaç sülüklerin oranının $\% 7$ olduğu tespit edilmiştir. Vücut ağırlı̆ı, vücut boyu ve kondisyon faktörü sırasıyla $0,52 \pm 1,19 \mathrm{~g}, 4,5 \pm 2,4 \mathrm{~cm}$ ve $0,620 \pm 0,123$ olarak belirlenmiştir. Bu çalışma Eğirdir Gölü çevresindeki sulak alanlarda yaşayan $H$. verbana popülasyonlarının büyük oranda korunduğunu ve popülasyonların sürdürülebilir yönetimi bakımından tehdit bulunmadığını ortaya çıkarmışıı. Eğirdir Gölü çevresi sulak alanlarında yaşayan tıbbi sülük popülasyonlarının korunmasında gölün istikrarlı su bütçesinin, tahrip edilmemiş habitatlardaki konakçı çeşitliliği, sülük toplayııılarının sosyoekonomik yapısı, sülük satış politikası ve koruma-kontrol birimlerinin faaliyetlerinin etkili olduğu düşünülmektedir.

Anahtar kelimeler: Ürün azaltma metodu, Bhattacharya metodu, vücut boyu frekansı, sürdürülebilir yönetim, koruma

\section{INTRODUCTION}

The trade of medicinal leech collected from nature is mostly based on $H$. verbana populations found in Turkish and Russian (Krasnodar Territory) wetlands (Trontelj and Utevsky, 2012; Sağlam et al., 2016). Although Turkey is an important supplier of medicinal leeches, leech gathering has been done without information of their biological characteristics, reproductive behavior, and population structure (Kasparek, 1998). The intensive use of leeches in medicine, habitat destruction and over-collecting have led to a gradual decrease of medicinal leech populations in European wetlands and they have completely disappeared in some wetlands (Elliott and Tullett, 1984; Elliott and Kutschera,
2011; Sağlam, 2011; Elliott and Dobson, 2015; Ceylan and Çetinkaya, 2017). International medicinal leech trade, therefore, is conducted under the Convention on International Trade in Endangered Species of Wild Fauna and Flora (CITES) (Collier et al., 2016; CITES, 2021; Uğural and Serezli, 2020). Export quota was established to 10,000 $\mathrm{kg} / \mathrm{year}$ in 1996 and has gradually declined for Turkey, which has about $80 \%$ of leech market of leeches collected from the wild, to 2,000 kg/year since 2014 (Sağlam 2011; Official Gazette, 2014; Official Gazette, 2020a). However, there is not enough information on the populations of $H$. verbana to form a basis for both export quota and international medicinal 
leech trade (Neubert and Nesemann, 1999; Kutschera, 2006; Kutschera and Roth, 2006; Elliott and Kutschera, 2011). Therefore, export quotas should be determined both realistically and reliably to manage the wild populations sustainably. For this purpose, sufficient and regularly updated information on the size and structure of the medicinal leech populations is required, especially in the wetlands where leech collection is conducted at the commercial level.

Because the population size is the most important information required for the conservation studies, scientific studies should be carried out especially on the exploited populations (Shaffer, 1981). The medicinal leech populations and their biological characteristics are largely neglected in scientific studies (Trontelj and Utevsky, 2005; Ceylan and Erbatur, 2012; Ceylan et al., 2019). Therefore, regular monitoring studies of medicinal leech populations and updated conservation policies are needed. In this study, it was aimed to investigate the structure and size of the medicinal leech, $H$. verbana populations inhabiting wetlands around Lake Eğirdir (Turkey), where leech collection has been carried out commercially. The removal methods to estimate population size were used for the first time for medicinal leech, $H$. verbana populations, and modal progression analysis of body length frequency to determine the age classes were used for the first time for all leech species (Hirudinea). The findings of the study can be used to conserve and manage sustainably the leech populations and habitats, and to provide more realistic export quotas for medicinal leech trade.

\section{MATERIALS AND METHODS}

\section{Study area}

This study was carried out in Akbük, Aşağı Tırtar, Boyall, Gelendost and Kayaağzı wetlands around Lake Eğirdir, areas located between $38^{\circ} 16^{\prime} 41^{\prime \prime}-37^{\circ} 50^{\prime} 31^{\prime \prime} \mathrm{N}$ and $030^{\circ} 44^{\prime} 49^{\prime \prime}$ $030^{\circ} 58^{\prime} 10^{\prime \prime} \mathrm{E}$ in the province of Isparta, Turkey (Figure 1). The wetlands selected for the present study are the main areas, where the commercial leech collection is conducted, around Lake Eğirdir. The studied wetlands are distinctly isolated from the lake, being far from each other, rich in macrophytes, being shallow, and rich in food in the form of hosts for leeches (Ceylan, 2016; Ceylan and Çetinkaya, 2017; Ceylan et al., 2021a).

The medicinal leeches were be collected in a total surface area of $110,300 \mathrm{~m}^{2}$ in the studied wetlands. The suitable surface areas were estimated as $4,400 \mathrm{~m}^{2}, 9,000 \mathrm{~m}^{2}, 22,600$ $\mathrm{m}^{2}, 24,000 \mathrm{~m}^{2}$ and $50,300 \mathrm{~m}^{2}$ in the wetlands of Boyal, Akbük, Aşağı Tırtar, Kayaağzı and Gelendost, respectively.

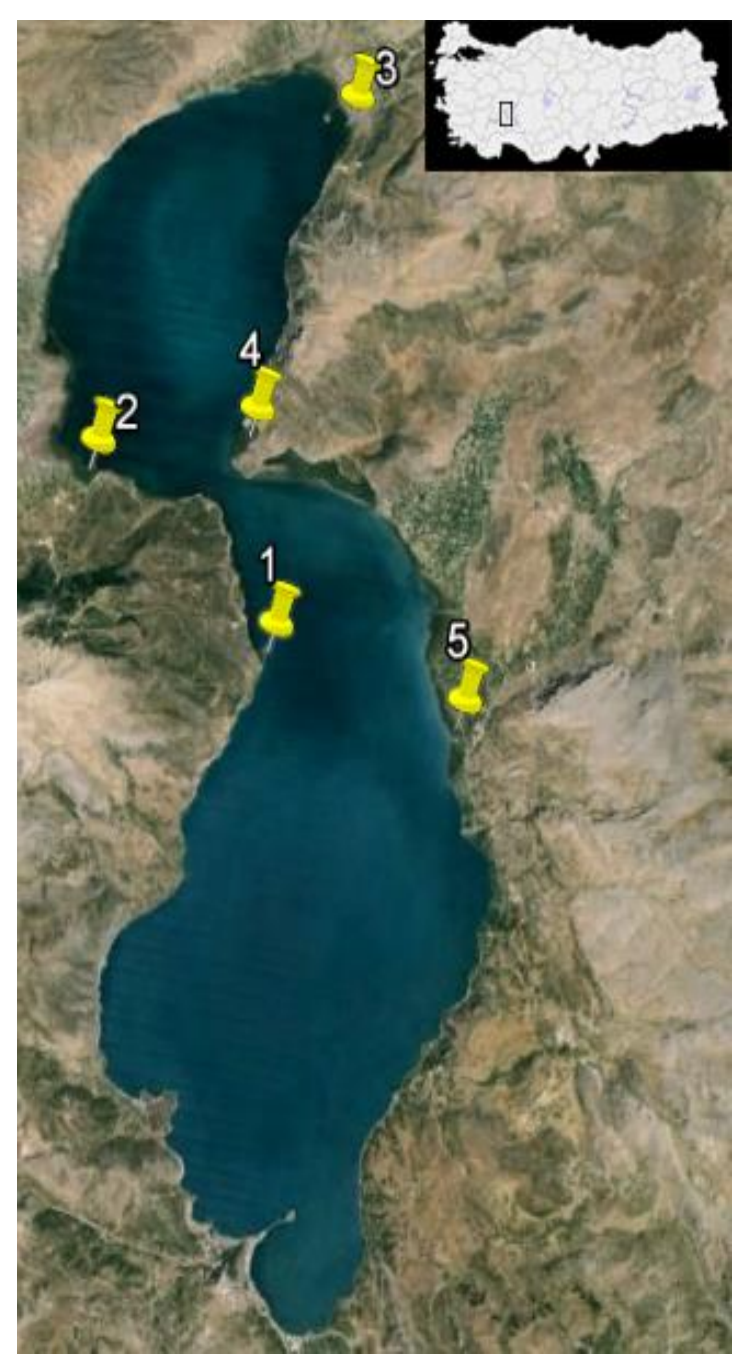

Figure 1. The wetlands around Lake Eğirdir where the present study was conducted. 1: Boyalı, 2: Kayaağzı, 3: Aşağı Tırtar, 4: Akbük, 5: Gelendost.

\section{Determination of population size}

The removal methods, "Maximum likelihood" (MLM) (Zippin, 1956) and "Regression" (RM) (Leslie and Davis, 1939), were used to estimate the population size of $H$. verbana. Removal methods aim to estimate population size using the decreasing trend of leeches withdrawn by successive collection operations. These methods were used in medicinal leeches for the first time in $H$. medicinalis by Elliott (2008) and successful results were obtained.

The present study was conducted in May, June, July, and August of 2014 when the water temperature was suitable $\left(>19^{\circ} \mathrm{C}\right)$ to activate the majority of leeches (Elliott and Tullett, 1986). The water temperature measured during the study per location and month was given in Table 1. 
Table 1. The water temperature measured and number of collected leeches per location and month.

\begin{tabular}{|c|c|c|c|}
\hline Locations & Months & $\begin{array}{l}\text { Water temperature } \\
\left({ }^{\circ} \mathrm{C}\right)\end{array}$ & $\begin{array}{c}\text { Number of collected } \\
\text { leeches }(n)\end{array}$ \\
\hline \multirow{5}{*}{ Akbük } & May & 30.7 & 53 \\
\hline & June & 31.7 & 276 \\
\hline & & & \\
\hline & July & 32.7 & 202 \\
\hline & August & 28.4 & 39 \\
\hline \multirow{5}{*}{ Aşağı Tırtar } & May & 26.5 & 205 \\
\hline & June & 28.1 & 431 \\
\hline & & & \\
\hline & July & 29.1 & 313 \\
\hline & August & 28.8 & 39 \\
\hline \multirow{5}{*}{ Boyalı } & May & 21.6 & 56 \\
\hline & June & 28 & 98 \\
\hline & & & \\
\hline & July & 29.8 & 10 \\
\hline & August & 27.8 & 4 \\
\hline \multirow{5}{*}{ Gelendost } & May & 25.4 & 442 \\
\hline & June & 26.7 & 751 \\
\hline & & & \\
\hline & July & 27.8 & 764 \\
\hline & August & 27.9 & 355 \\
\hline \multirow{5}{*}{ Kayaağzı } & May & 21.7 & 28 \\
\hline & June & 27.5 & 342 \\
\hline & & & \\
\hline & July & 30.4 & 293 \\
\hline & August & 28.6 & 83 \\
\hline \multirow{5}{*}{ All habitats } & May & $25.2 \pm 3.8$ & 784 \\
\hline & June & $28.4 \pm 1.9$ & 1,898 \\
\hline & & & \\
\hline & July & $30.0 \pm 1.8$ & 1,583 \\
\hline & August & $28.3 \pm 0.4$ & 520 \\
\hline
\end{tabular}

In total, four catch operations, each of which lasted for 45 minutes, were performed in each habitat by rotating clockwise in the certain surface areas. The leeches were stimulated to swim by disturbing the water by collectors. The leeches, which are actively swimming and attaching to the fishing boot, were collected, and put into $5 \mathrm{~L}$ pet jars which were labelled accordingly. Between the catch operations, 15 minutes were left as the break. All leeches collected during the study ( $n=$ 4,784 ) were transported to the laboratory for counting and weighing, and afterwards all leeches were released in the wetlands, where they were collected. The collected leech number per location and month was given in Table 1.

The equations of the removal methods used in the present study are explained in detail below.

Maximum likelihood method: The population size in this method was estimated using following equations according to Zippin (1956).

$$
N=\sum n i /\left(1-q^{s}\right)
$$

where "N" is the population size, " $\sum \mathrm{ni}$ " is the sum of all collected leeches, "s" is the number of catch operation runs, and "q" is the probability of a leech not being caught. " $q$ " was determined following equation.

$$
q=\left(\sum n i-C_{1}\right) /\left(\sum \text { ni }-C_{s}\right)
$$

where " $\mathrm{C}_{1}$ " is the number of leeches caught in the first operation and " $\mathrm{C}_{s}$ " is the number of leeches caught in " $\mathrm{s}$ " operations.

Regression method: The population size in this method was estimated using following equation according to Elliott (2008).

$$
N=m+(n / p)
$$

where " $\mathrm{N}$ " is the population size, " $\mathrm{m}$ " is mean of the cumulative sum of the collected leeches except in the last catch operation, ""n" is the mean of the sum of the collected leeches for all catch operations and " $p$ " is the slope of the regression line between the sum of the previous operations and the number of leeches caught on each successive catch operation.

These methods were applied in the sub-areas representing the studied wetlands. A proportion coefficient for each wetland was determined dividing the suitable surface area to sampling area. The estimated population size in the sub-areas was multiplied with proportion coefficient to estimate the total population size in each wetland.

\section{Determination of biometric properties of leeches}

All leeches were weighed, but since body length measurement has some technical difficulties, body length 
measurement was conducted in only some of them $(n=$ 1,214). To measure the body length, leeches were anesthetized for $15 \mathrm{~min}$ in $2.5 \mathrm{ml} / \mathrm{L}$ phenoxyethanol solution $\left(25^{\circ} \mathrm{C}\right)$. Body length, the distance between the endpoints of the anterior and posterior suckers, was measured with a precision of $1 \mathrm{~mm}$ when they were anesthetized (Ceylan et al., 2021b). Condition factor (K) was calculated using the standard formula [K = (Body weight) / (Body length $)^{3} \times 100$ ] according to Ricker (1975). The body weight frequency of the leech populations was determined. Since the majority distribution was densified in small weights (right skewed), the axis showing the weight in the graph has been log scaled in especially small weights to show the weight distribution more clearly.

\section{Determination of age classes}

The age classes of the medicinal leech populations were estimated by Modal Progression Analysis (Bhattacharya's method) based on body length frequencies using FISAT II v.1.2.2 package software. Modal progression analysis uses the methodology which infers the growth from the apparent shift of modes or means in a time series length-frequency sample. The lowest separation index was considered as "2" for distinguishing age classes (Gayanilo et al., 2005).

\section{Statistical analysis}

Normality of data was tested by Kolmogorov-Smirnov test. One-way ANOVA test or Kruskal-Wallis rank order test was applied according to normality test results. While the Duncan post-hoc test was used for comparison of normally distributed data, Tukey HSD post-hoc test was used for non-normally distributed data. The results obtained from the removal methods used to determine the population size were evaluated by the Chi-Square Test of Independence. Relationship between average body weight and leech number per catch operation was determined using Regression analysis (Özdamar, 2011). The results are given as mean \pm standard deviation $(X \pm S D)$. The significance level was accepted as $a=0.05$. Data were analyzed using IBM SPSS Statistics version 25.0 for Windows package software (IBM Corp., Armonk, NY, USA).

\section{Legal permissions and ethical statements}

The medicinal leech, Hirudo verbana is an endangered species and whose international trade is regulated by the
CITES. The present study, therefore, was carried out getting the legal permission (Date: 24.12.2012, Number: 05757) from the Ministry of Food, Agriculture and Livestock (currently Ministry of Agriculture and Forestry), General Directorate of Fisheries and Aquaculture, the management authority for the CITES in Turkey.

The present study was conducted under the Regulation on the Working Procedures and Principles of Animal Experiments Ethics Committees of Turkey. Accordingly, only experiments conducted on vertebrate animals require review and approval by the Ethics Committees, and thus leeches did not require approval.

\section{RESULTS}

\section{Estimated size of the medicinal leech populations}

Since the response of leeches to collecting effort differs by season, and because the composition of the population size also differs according to the sampling date, the results of four months were averaged. The mean population size and biomass were estimated as 1,552,042 $\pm 778,378$ leeches and $463.85 \pm 166.43 \mathrm{~kg}$, respectively by $\mathrm{RM}$, and 1,562,696 \pm 805,613 leeches and $467.26 \pm 172.91 \mathrm{~kg}$, respectively by MLM. The population size determined by methods of RM and MLM are very close to each other $(x 2=2819.074, d f=19, P$ $<0.001)$. The difference in population size between the two methods is approximately $7 \%$.

Population size tended to increase from May to July. It was estimated to 829,806 leeches $(357 \mathrm{~kg}$ ) in May, increased to $2,565,122$ leeches $(715 \mathrm{~kg})$ in July, and sharply decreased to 998,552 leeches $(340 \mathrm{~kg}$ ) in August.

The Boyalı wetland has the smallest population size with 2,106 $\pm 3,163$ leeches $(3.04 \pm 4.15 \mathrm{~kg})$ and the Gelendost wetland has the biggest population size with 1,205,999 \pm 514,871 leeches $(260.93 \pm 139.18 \mathrm{~kg})$. Gelendost wetland was followed by Aşağı Tırtar $(117,045 \pm 80,182$ leeches $111.55 \pm 85.76 \mathrm{~kg})$ and Kayaağzı $(212,297 \pm 208,751$ leeches $-72.15 \pm 49.48 \mathrm{~kg}$ ), respectively. The difference in population size among habitats was significant $(P<0.05)$. The mean population size in studied wetlands was estimated as $1,562,696 \pm 805,613$ leeches and $467.26 \pm 172.91 \mathrm{~kg}$ biomass. Monthly change of size of the medicinal leech populations per habitat is given in Table 2 . 
Table 2. Monthly change of size (abundance and biomass) of the medicinal leech, $H$. verbana populations per habitats.

\begin{tabular}{|c|c|c|c|c|c|c|c|}
\hline \multirow{2}{*}{ Habitats } & \multirow{2}{*}{ Parameters } & \multirow{2}{*}{$\begin{array}{l}\text { Method } \\
\text { (*) }\end{array}$} & \multicolumn{5}{|c|}{ Months (2014) } \\
\hline & & & May & June & July & August & Average $(X \pm S D)$ \\
\hline \multirow{7}{*}{ Boyalı } & \multirow{3}{*}{ Abundance } & RM & $820 \pm 3$ & $6,833 \pm 56$ & $476 \pm 25$ & $251 \pm 0$ & $2,095 \pm 3,167^{a}$ \\
\hline & & & & & & & \\
\hline & & MLM & $851 \pm 2$ & $6,836 \pm 35$ & $486 \pm 19$ & $251 \pm 0$ & $2,106 \pm 3,163^{a}$ \\
\hline & & & & & & & \\
\hline & \multirow{3}{*}{ Biomass $(\mathrm{kg})$} & RM & $1.97 \pm 0.00$ & $9.16 \pm 0.07$ & $0.55 \pm 0.03$ & $0.38 \pm 0.00$ & $3.02 \pm 4.16^{\mathrm{A}}$ \\
\hline & & & & & & & \\
\hline & & MLM & $2.04 \pm 0.00$ & $9.16 \pm 0.04$ & $0.56 \pm 0.02$ & $0.38 \pm 0.00$ & $3.04 \pm 4.15^{B}$ \\
\hline \multirow{7}{*}{ Akbük } & \multirow{3}{*}{ Abundance } & $\mathrm{RM}$ & $5,660 \pm 129$ & $32,970 \pm 176$ & $50,855 \pm 309$ & $11,551 \pm 5$ & $25,259 \pm 20,709^{a}$ \\
\hline & & & & & & & \\
\hline & & MLM & $5,480 \pm 79$ & $32,692 \pm 106$ & $51,124 \pm 213$ & $11,701 \pm 3$ & $25,249 \pm 20,811^{a}$ \\
\hline & \multirow{4}{*}{ Biomass $(\mathrm{kg})$} & & & & & & \\
\hline & & $\mathrm{RM}$ & $14.04 \pm 0.20$ & $12.86 \pm 0.11$ & $35.60 \pm 0.26$ & $16.06 \pm 0.01$ & $19.64 \pm 10.72^{\mathrm{A}}$ \\
\hline & & & & & & & \\
\hline & & MLM & $13.59 \pm 0.12$ & $12.75 \pm 0.07$ & $35.79 \pm 0.18$ & $16.26 \pm 0.00$ & $19.60 \pm 10.90^{A}$ \\
\hline \multirow{7}{*}{ Kayaağzı } & \multirow{3}{*}{ Abundance } & $\mathrm{RM}$ & $19,290 \pm 215$ & $365,047 \pm 1,891$ & $443,416 \pm 1,344$ & $52,633 \pm 207$ & $220,097 \pm 215,445^{a}$ \\
\hline & & & & & & & \\
\hline & & MLM & $19,301 \pm 148$ & $335,901 \pm 1,278$ & $441,668 \pm 953$ & $52,316 \pm 131$ & $212,297 \pm 208,751^{a}$ \\
\hline & & & & & & & \\
\hline & \multirow{3}{*}{ Biomass $(\mathrm{kg})$} & $\mathrm{RM}$ & $19.68 \pm 0.22$ & $105.86 \pm 1.02$ & $128.59 \pm 0.72$ & $43.69 \pm 0.19$ & $74.46 \pm 51.20^{A}$ \\
\hline & & & & & & & \\
\hline & & MLM & $19.69 \pm 0.15$ & $97.41 \pm 0.69$ & $128.08 \pm 0.51$ & $43.42 \pm 0.12$ & $72.15 \pm 49.48^{A}$ \\
\hline \multirow{7}{*}{ Aşağı Tırta } & \multirow{3}{*}{ Abundance } & $\mathrm{RM}$ & $77,652 \pm 136$ & $186,045 \pm 383$ & $178,649 \pm 222$ & $22,967 \pm 81$ & $116,328 \pm 79,491^{a}$ \\
\hline & & & & & & & \\
\hline & & MLM & $78,709 \pm 94$ & $186,718 \pm 258$ & $180,347 \pm 145$ & $22,406 \pm 46$ & $117,045 \pm 80,182^{a}$ \\
\hline & \multirow{4}{*}{ Biomass $(\mathrm{kg})$} & & & & & & \\
\hline & & RM & $224.41 \pm 0.23$ & $78.14 \pm 0.25$ & $114.34 \pm 0.18$ & $25.49 \pm 0.03$ & $110.60 \pm 84.19 \mathrm{AB}$ \\
\hline & & & & & & & \\
\hline & & MLM & $227.47 \pm 0.16$ & $78.42 \pm 0.17$ & $115.42 \pm 0.12$ & $24.87 \pm 0.05$ & $111.55 \pm 85.76^{A B}$ \\
\hline \multirow{7}{*}{ Gelendost } & \multirow{3}{*}{ Abundance } & $\mathrm{RM}$ & $748,918 \pm 2,013$ & $1,282,646 \pm 2,614$ & $1,827,074 \pm 4,033$ & $894,416 \pm 482$ & $1,188,264 \pm 481,788^{b}$ \\
\hline & & & & & & & \\
\hline & & MLM & $725,465 \pm 1,336$ & $1,295,157 \pm 1,964$ & $1,891,497 \pm 3,203$ & $911,878 \pm 339$ & $1,205,999 \pm 514,871^{b}$ \\
\hline & \multirow{4}{*}{ Biomass (kg) } & & & & & & \\
\hline & & $\mathrm{RM}$ & $97.36 \pm 0.73$ & $256.53 \pm 1.17$ & $420.23 \pm 1.93$ & $250.44 \pm 0.26$ & $256.14 \pm 131.87^{B}$ \\
\hline & & & & & & & \\
\hline & & MLM & $94.31 \pm 0.48$ & $259.03 \pm 0.88$ & $435.04 \pm 1.54$ & $255.33 \pm 0.18$ & $260.93 \pm 139.18^{B}$ \\
\hline \multirow{7}{*}{ All habitats } & \multirow{3}{*}{ Abundance } & $\mathrm{RM}$ & 852,340 & $1,873,541$ & $2,500,470$ & 981,818 & $1,552,042 \pm 778,378$ \\
\hline & & & & & & & \\
\hline & & MLM & 829,806 & $1,857,304$ & $2,565,122$ & 998,552 & $1,562,696 \pm 805,613$ \\
\hline & \multirow{4}{*}{ Biomass $(\mathrm{kg})$} & & & & & & \\
\hline & & $\mathrm{RM}$ & 357.46 & 462.55 & 699.31 & 336.06 & $463.85 \pm 166.43$ \\
\hline & & & & & & & \\
\hline & & MLM & 357.10 & 456.77 & 714.89 & 340.26 & $467.26 \pm 172.91$ \\
\hline
\end{tabular}

(*) RM: Regression Method (Leslie and Davis, 1939), MLM: Maximum Likelihood Method (Zippin, 1956). The difference of the estimated number of leeches (abundance) and biomass of the populations among the habitats are shown by lower and upper cases respectively $(P<0.05)$. 
In addition to the studied wetlands, leech collecting is carried out also in the wetlands of Yenice, Gençali and between Boyalı and Akkeçili located around Lake Eğirdir. However, the current study was conducted in only five wetlands due to technical possibilities. When the suitable surface area (approximately $30,000 \mathrm{~m}^{2}$ ) of the nonstudied areas was taken into consideration, the total population size and biomass of medicinal leeches around Lake Eğirdir was estimated as 1,988,700 leeches and $593 \mathrm{~kg}$, respectively.

\section{Biometric features of the populations}

The mean body weight, body length and condition factor of the medicinal leech populations in all habitats were estimated as $0.52 \pm 1.19 \mathrm{~g}(\min =0.0182 \mathrm{~g}$, $\max =13.10 \mathrm{~g})$, $4.5 \pm 2.4 \mathrm{~cm}(\min =1.4 \mathrm{~cm}, \max =12.0 \mathrm{~cm})$ and $0.620 \pm$ $0.123(\min =0.260, \max =1.252)$, respectively. $89.9 \%$ of leeches in the populations weighed less than $1 \mathrm{~g}$. The smallest gravid leech in populations of $H$. verbana weighted $1.69 \mathrm{~g}$ (Ceylan, 2016). The percentage of the leeches bigger than $1.69 \mathrm{~g}$, representing gravid specimens, was only $7.0 \%$ in this study. The frequency of the medicinal leech, $H$. verbana populations according to the weight classes is given in Figure 2.

The differences of the body weight, body length and condition factor among the habitats was significant considering the data of all months $(P<0.05)$. The biggest leeches $(1.69 \pm 1.70 \mathrm{~g}$ and $6.0 \pm 2.2 \mathrm{~cm})$ were collected from the Boyalı, which has the lowest catch amount and population size, while the smallest ones $(0.21 \pm 0.57 \mathrm{~g}$ and $3.5 \pm 2.0 \mathrm{~cm})$ were collected from the Gelendost, which has the highest catch amount and population size. The leeches having the lowest mean condition $(0.590 \pm 0.111)$ were found in Boyalı, which hosts the largest leeches. The highest mean condition $(0.650 \pm 0.135)$ of the populations was obtained from Kayaağzı (Table 3).

There was a negative significant correlation $(r=-0.620, P$ $<0.01)$ and second order polynomial regression $\left(R^{2}=0.761\right.$, $P<0.001$ ) between the size and catch amount (Figure 3).

The differences of the sizes and condition factors of the leeches among the months were significant considering the data of all habitats $(P<0.05)$. The mean body weight and body length of the medicinal leech populations with $1.21 \pm$ $2.09 \mathrm{~g}$ and $5.3 \pm 3.2 \mathrm{~cm}$ in May decreased to $0.35 \pm 0.94 \mathrm{~g}$ and $4.5 \pm 2.4 \mathrm{~cm}$ in June and then gradually increased to $0.52 \pm 0.67 \mathrm{~g}$ and $4.3 \pm 1.7 \mathrm{~cm}$ in August. The mean condition factor was found to be the lowest in June with $0.602 \pm 0.107$ and the highest in August with $0.664 \pm 0.136$ (Table 3).

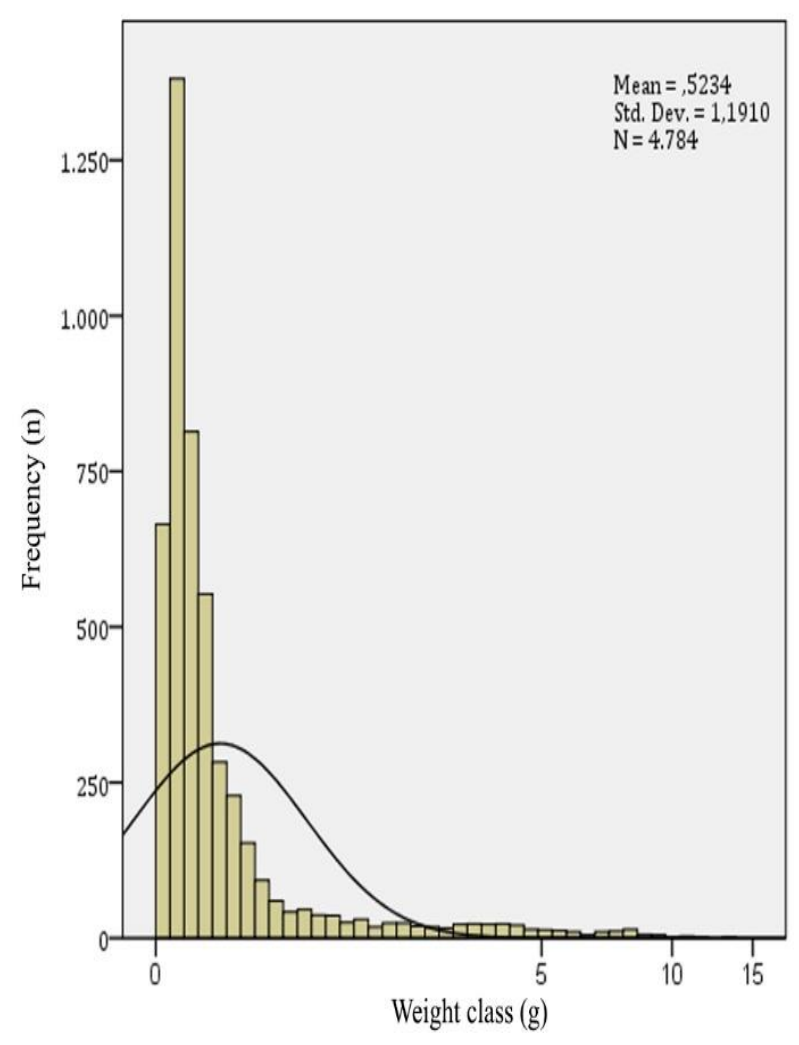

Figure 2. The body weight frequency of the medicinal leech, $\mathrm{H}$. verbana populations.

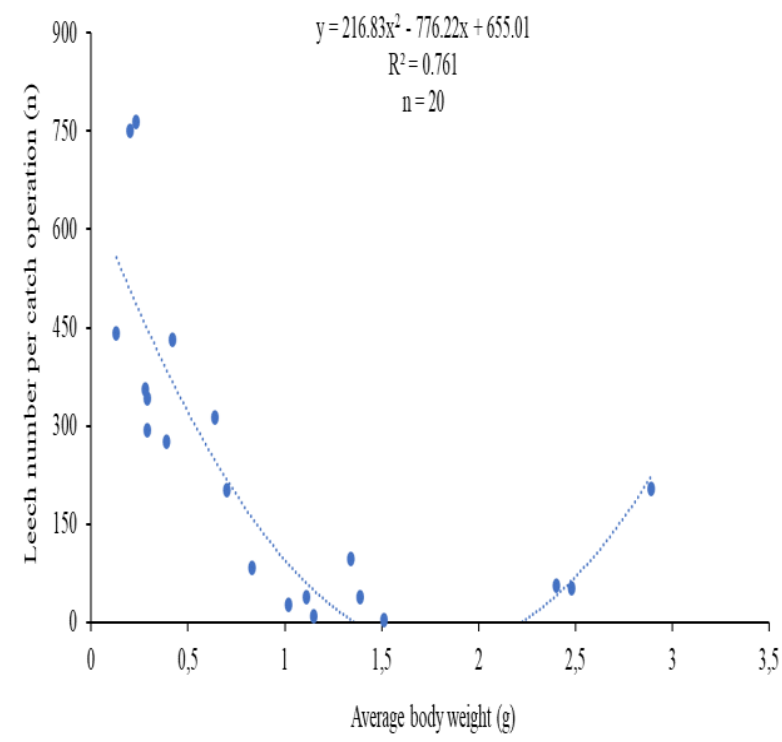

Figure 3. Relationship between average body weight and leech number per catch operation. 
Table 3. The body weight, body length and condition factor the medicinal leeches by months and habitats $(X \pm S D)$.

\begin{tabular}{|c|c|c|c|c|}
\hline Months & Habitats & Body weight (g) & Body length $(\mathrm{cm})$ & Condition factor \\
\hline \multirow{6}{*}{ May } & Kayaağzı & $1.02 \pm 1.34^{\mathrm{Ab}}$ & $4.2 \pm 2.8^{A b c}$ & $0.593 \pm 0.111^{A}$ \\
\hline & Aşağı Tırtar & $2.89 \pm 2.55^{\mathrm{Aa}}$ & $6.4 \pm 3.0^{\mathrm{Aa}}$ & $0.609 \pm 0.114^{B}$ \\
\hline & Gelendost & $0.13 \pm 0.48^{\mathrm{Bc}}$ & $3.2 \pm 2.2^{\mathrm{BC}}$ & $0.610 \pm 0.133$ \\
\hline & Akbük & $2.48 \pm 3.26^{\mathrm{Aa}}$ & $5.4 \pm 3.6^{\mathrm{ABab}}$ & $0.644 \pm 0.099 A B$ \\
\hline & Boyalı & $2.40 \pm 1.56^{a}$ & $6.6 \pm 2.6^{a}$ & $0.607 \pm 0.159$ \\
\hline & All habitats & $1.21 \pm 2.09$ & $5.3 \pm 3.2$ & $0.614 \pm 0.122$ \\
\hline \multirow{6}{*}{ June } & Kayaağzı & $0.29 \pm 0.82^{\mathrm{Bb}}$ & $3.9 \pm 2.4^{\mathrm{ABb}}$ & $0.629 \pm 0.121^{\mathrm{Aa}}$ \\
\hline & Aşağı Tırtar & $0.42 \pm 1.04 \mathrm{Bb}$ & $4.5 \pm 2.4 \mathrm{Bb}$ & $0.620 \pm 0.112^{\mathrm{ABa}}$ \\
\hline & Gelendost & $0.20 \pm 0.71^{A B b}$ & $4.1 \pm 2.7^{\mathrm{Ab}}$ & $0.599 \pm 0.109 \mathrm{ab}$ \\
\hline & Akbük & $0.39 \pm 0.82^{\mathrm{Cb}}$ & $4.3 \pm 2.0^{\mathrm{Bb}}$ & $0.562 \pm 0.088^{\mathrm{Bb}}$ \\
\hline & Boyalı & $1.34 \pm 1.77^{a}$ & $5.6 \pm 2.2^{\mathrm{a}}$ & $0.592 \pm 0.086^{\mathrm{ab}}$ \\
\hline & All habitats & $0.35 \pm 0.94$ & $4.5 \pm 2.4$ & $0.602 \pm 0.107$ \\
\hline \multirow{6}{*}{ July } & Kayaağzı & $0.29 \pm 0.48^{\mathrm{Bbc}}$ & $3.5 \pm 1.5^{\mathrm{Bc}}$ & $0.633 \pm 0.124 \mathrm{Aa}$ \\
\hline & Aşağı Tırtar & $0.64 \pm 0.96 \mathrm{ABbc}$ & $4.8 \pm 2.1 \mathrm{Bb}$ & $0.672 \pm 0.154^{\mathrm{Aa}}$ \\
\hline & Gelendost & $0.23 \pm 0.50^{A C}$ & $3.4 \pm 1.7^{\mathrm{ABC}}$ & $0.595 \pm 0.113^{a b}$ \\
\hline & Akbük & $0.70 \pm 1.38 \mathrm{Cb}$ & $4.9 \pm 2.0 \mathrm{ABab}$ & $0.599 \pm 0.091 \mathrm{BCab}$ \\
\hline & Boyalı & $1.15 \pm 0.36^{a}$ & $6.0 \pm 0.8^{a}$ & $0.529 \pm 0.070^{b}$ \\
\hline & All habitats & $0.39 \pm 0.79$ & $4.0 \pm 1.9$ & $0.617 \pm 0.123$ \\
\hline \multirow{6}{*}{ August } & Kayaağzı & $0.83 \pm 0.82^{\mathrm{Ab}}$ & $4.5 \pm 1.6^{\mathrm{Abc}}$ & $0.728 \pm 0.148^{\mathrm{Aa}}$ \\
\hline & Aşağı Tırtar & $1.11 \pm 0.65^{\mathrm{Bab}}$ & $5.4 \pm 1.2^{\mathrm{ABab}}$ & $0.665 \pm 0.075^{\text {ABab }}$ \\
\hline & Gelendost & $0.28 \pm 0.49 A c$ & $3.3 \pm 1.3 \mathrm{BC}$ & $0.631 \pm 0.139 \mathrm{ab}$ \\
\hline & Akbük & $1.39 \pm 0.31 \mathrm{Ba}$ & $6.0 \pm 0.5^{\mathrm{Aa}}$ & $0.658 \pm 0.122^{\mathrm{Aab}}$ \\
\hline & Boyalı & $1.51 \pm 0.35^{a}$ & $6.4 \pm 0.7^{a}$ & $0.566 \pm 0.060^{b}$ \\
\hline & All habitats & $0.52 \pm 0.67$ & $4.3 \pm 1.7$ & $0.664 \pm 0.136$ \\
\hline \multirow{6}{*}{ All months } & Kayaağzı & $0.38 \pm 0.76^{a}$ & $4.0 \pm 2.0^{a}$ & $0.650 \pm 0.135^{c}$ \\
\hline & Aşağı Tırtar & $1.03 \pm 1.75^{c}$ & $5.3 \pm 2.6^{b}$ & $0.634 \pm 0.123 \mathrm{bc}$ \\
\hline & Gelendost & $0.21 \pm 0.57^{a}$ & $3.5 \pm 2.0^{a}$ & $0.608 \pm 0.124^{a b}$ \\
\hline & Akbük & $0.76 \pm 1.53^{b}$ & $4.9 \pm 2.4^{b}$ & $0.603 \pm 0.101^{a b}$ \\
\hline & Boyalı & $1.69 \pm 1.70^{d}$ & $6.0 \pm 2.2^{c}$ & $0.590 \pm 0.111^{a}$ \\
\hline & All habitats & $0.52 \pm 1.19$ & $4.5 \pm 2.4$ & $0.620 \pm 0.123$ \\
\hline
\end{tabular}

While the difference of body weight, body length and condition factor among the habitats was shown with lower case $(P<0.05)$, the difference among the months was shown with upper case $(P<0.05)$. 


\section{Age groups in the medicinal leech populations}

Three distinct classes representing $0+, 1+$ and $2+$ ages were identified by analysis of body length frequencies using the Bhattacharya's method. The mean body length for each age class was estimated as $2.96 \pm 1.35 \mathrm{~cm}(0+), 7.20 \pm 1.01$ $\mathrm{cm} \mathrm{(1+)}$ and $9.79 \pm 1.06 \mathrm{~cm}(2+)$, respectively (Table 4). According to the Table 4, body length of the leeches has decreased in general due to the continued participation of baby leeches in the population living in the water during the study. While the dominant age group was $0+$ with $78.6 \%$, the percentage of $1+$ and $2+$ age groups were $12.8 \%$ and $8.6 \%$, respectively. The age classes of the medicinal leech, Hirudo verbana populations are given in Figure 4.

Table 4. Monthly changes of the body length, number of leeches, percentage, and the body length frequency separation index (S.I.) in age classes for all habitats.

\begin{tabular}{|c|c|c|c|c|}
\hline \multirow{2}{*}{ Months } & \multirow{2}{*}{ Parameters } & \multicolumn{3}{|c|}{ Age classes } \\
\hline & & $0+$ & $1+$ & $2+$ \\
\hline \multirow{3}{*}{ May } & $\begin{array}{l}\text { Body length } \\
\mathrm{cm}\end{array}$ & $2.50 \pm 0.62$ & $7.52 \pm 1.69$ & $10.56 \pm 0.95$ \\
\hline & $\begin{array}{l}\text { Percentage } \\
(\%)\end{array}$ & $146(55.9 \%)$ & $89(34.1 \%)$ & $26(10 \%)$ \\
\hline & S.I. & n.a. ${ }^{*}$ & 3.740 & 2.090 \\
\hline \multirow{3}{*}{ June } & $\begin{array}{l}\text { Body length } \\
\mathrm{cm}\end{array}$ & $3.11 \pm 0.81$ & $8.20 \pm 1.12$ & $10.29 \pm 0.73$ \\
\hline & $\begin{array}{l}\text { Percentage } \\
(\%)\end{array}$ & $222(76.3 \%)$ & $41(14.1 \%)$ & $28(9.6 \%)$ \\
\hline & S.I. & n.a. & 3.610 & 2.050 \\
\hline \multirow{3}{*}{ July } & $\begin{array}{l}\text { Body length } \\
\mathrm{cm}\end{array}$ & $3.57 \pm 0.86$ & $5.50 \pm 0.99$ & $8.92 \pm 1.98$ \\
\hline & $\begin{array}{l}\text { Percentage } \\
(\%)\end{array}$ & $320(83.6 \%)$ & $28(7.3 \%)$ & $35(9.1 \%)$ \\
\hline & S.I. & n.a. & 2.040 & 2.140 \\
\hline \multirow{3}{*}{ August } & $\begin{array}{l}\text { Body length } \\
\mathrm{cm}\end{array}$ & $3.07 \pm 1.35$ & $6.07 \pm 0.81$ & $8.50 \pm 1.24$ \\
\hline & $\begin{array}{l}\text { Percentage } \\
(\%)\end{array}$ & $165(70.8 \%)$ & $65(27.9 \%)$ & $3(1.3 \%)$ \\
\hline & S.I. & n.a. & 2.380 & 2.110 \\
\hline \multirow{3}{*}{$\begin{array}{l}\text { All } \\
\text { months }\end{array}$} & $\begin{array}{l}\text { Body length } \\
\mathrm{cm}\end{array}$ & $2.96 \pm 1.35$ & $7.20 \pm 1.01$ & $9.79 \pm 1.06$ \\
\hline & $\begin{array}{l}\text { Percentage } \\
(\%)\end{array}$ & $\begin{array}{l}1073 \\
(78.6 \%)\end{array}$ & 175 (12.8\%) & $118(8.6 \%)$ \\
\hline & S.I. & n.a. & 2.870 & 2.130 \\
\hline
\end{tabular}

${ }^{*}$ n.a. methodologically not assessed.
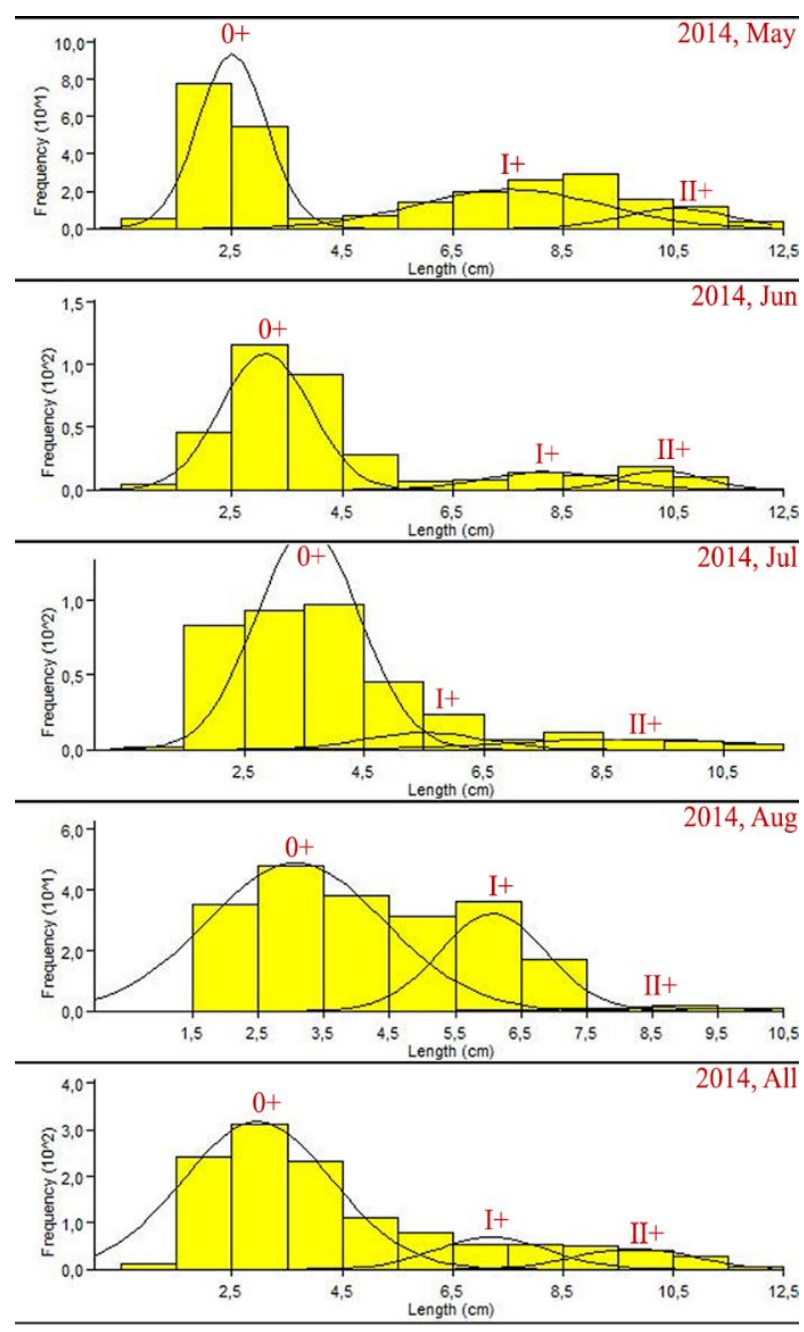

Figure 4. The age classes of the medicinal leech, $H$. verbana populations which were determined by the Bhattacharya's method.

\section{DISCUSSION}

In total, three age groups were identified in the studied medicinal leech populations. However, 4 size groups (age classes) were depicted in the Hirudo medicinalis populations inhabiting Jenny Dam (Lake District, England) (Elliott, 2008). In the study conducted by Elliott (2008) the oldest group, representing 4 years old leeches, represented only $1 \%$ of the population. This may indicate the difficulty of sampling large leeches that withdraw from the habitats subjected to leech harvesting before reaching older ages.

The body weight of the leeches varied between $0.0182 \mathrm{~g}$ and $13.10 \mathrm{~g}$ in this study. The body weight range of the leeches was $0.23-5.63 \mathrm{~g}$ in Akpınar Marsh, Turkey (Sağlam et al., 2018) and $0.1-15.8 \mathrm{~g}$ in Lake Efteni and Lake Poyrazlar, Turkey (Demirsoy et al., 2001). The studies conducted in some Turkish wetlands revealed that the mean body weight of the medicinal leech populations decline gradually from the spring months until June-July and then 
increase (Demirsoy et al., 2001; Ceylan, 2016). The mean body weight of the population was $1.21 \pm 2.09 \mathrm{~g}$ in May, then decreased sharply to $0.35 \pm 0.94 \mathrm{~g}$ in June and then gradually increased in the present study. This can be explained by the effects of the water level of the lake on the structure of medicinal leech populations. The gravid leeches of both $H$. medicinalis and $H$. verbana populations leave the water and deposit the cocoons in damp places in July, August and September (Wilkin, 1989; Elliott and Dobson, 2015; Ceylan, 2016). The water level gradually falls during this period. The cocoon incubation period lasts approximately 30 days in $H$. verbana populations (Kutschera and Roth, 2006; Petrauskienè et al., 2009; Ceylan et al., 2015). Decreasing the water level of lake during the cocoon incubation period causes leeches, which wait passively in the soil part of the habitat, to delay participation into populations living in the water. According to Ceylan (2016) the waiting period can last for 9-10 months, depending on both the water level rising and the distance of the overwintering cocoons to the water line of wetlands. Hatchlings live in the moist microhabitats during this period. When leeches started to deposit cocoons in July 2013, the water level of Lake Eğirdir was 917.77 m (Ceylan, 2016). However, the water level of the lake was able to rise to $917.68 \mathrm{~m}$ in following year (2014), then it gradually fell (Ceylan, 2016). As the highest water level in 2014 didn't reach the level at the beginning of the reproduction period in 2013, until June 2014 the entrance of offspring to the populations living in lake water continued. The mean body weight of the population decreased to the lowest value of 0.35 $\pm 0.94 \mathrm{~g}$ in this month. After this, the mean body weight of the populations increased gradually to $0.52 \pm 0.67 \mathrm{~g}$ in August due to both the end of the entrance of offspring to the lake's water and that the leeches had the opportunity to feed regularly in lake's water.

In addition to the studied wetlands, also a couple of wetlands serve as habitat for medicinal leeches in Lake Eğirdir. Considering the surface areas of these habitats the size of medicinal leeches population in Lake Eğirdir is estimated at $1,988,700$ leeches. According to this, the populations of $H$. verbana in the wetlands around Lake Eğirdir are much larger in comparison to the populations of $H$. medicinalis inhabiting Jenny Dam (248-289 leeches) (Elliott, 2008) and Dungeness (England) (more than 10,000 leeches) (Wilkin and Scofield, 1991). The size of medicinal leech populations in studied wetlands is higher than in the other 21 wetlands except for the population of the medicinal leech population in Doğubeyazıt Marsh, which was estimated to $17,500,000$ leeches (Sağlam et al., 2008). The size of the studied medicinal leech populations is also higher than in the other 10 wetlands except for the population of the medicinal leech population in Beyşehir Lake, Turkey, which was estimated to 2,890,000 leeches (Anonymous, 1997).

It is thought that decline of the water level of the lake and the reproduction period are responsible for the sharp decrease in the estimated population size in August. In addition to this, it is considered that medicinal leeches (Hirudo $\mathrm{sp}$.) becoming inactive after feeding for a long time can cause this result. Some of the leeches, which moved to the humid terrestrial areas of the habitats to lay cocoons, remain in these areas far from the water because of the decrease of lake water level. Sampling different sized leeches in the moist terrestrial areas of 200-300 m distance from the water and in the puddles revealed that some of the leeches passively wait in terrestrial areas without returning to the water until the water level increases. The ability of adaptation to arid conditions compared to other medicinal leech species should be considered as an assurance and the populations of $H$. verbana can tolerate the lake level cycle. The fact that the leeches remain in terrestrial environment due to the decrease in the water level of the lake provides an opportunity to naturally protect them from the pressure of leech-collecting, which occurs by catching individuals actively swimming in the water.

The medicinal leech population size was estimated as $1,796,000$ leeches and biomass as $2,739 \mathrm{~kg}$ in the same wetlands 20 years ago in Lake Eğirdir (Anonymous, 1997). Although the population size in the present study is only slightly larger, the difference of the estimated biomass between both studies is quite high. The estimated biomass in the mentioned study was determined using an average individual body weight $(1.525 \mathrm{~g})$ for all wetlands. This difference occurred because of the low mean body weight $(0.21 \pm 0.57 \mathrm{~g})$ of the population in Gelendost wetland, which has about $77 \%$ of the total estimated population size. It is thought that the number of leeches provides a more realistic assessment rather than biomass due to the fact that medicinal leeches can consume 8.9 times their own body weight in a feeding period (Dickinson and Lent, 1984).

Mediterranean medicinal leech, $H$. verbana populations living in wetlands around Lake Eğirdir deposit the cocoons from July to September when the water level of the lake decreases (Ceylan, 2016). Breeding season of $H$. medicinalis seems to be the same as of $H$. verbana, according to some studies conducted with $H$. medicinalis populations (Sawyer, 1986; Wilkin, 1989; Elliott and Kutschera, 2011; Kutschera and Elliott, 2014). However, the prohibition season is valid from 1 March to 30 June, according to the "Notification No. 4/1 Regulating Commercial Fisheries" in Turkey. It is thought that misapplying leech collection prohibition season may be due to insufficient knowledge on phenology and reproduction ecology of the $H$. verbana populations. Furthermore, also catch quantity restriction is not applied for medicinal leeches in Turkey (Official Gazette, 2020b). Despite commercial leech collection carrying out without the catch quantity restriction and misapplying the prohibition season, it is thought that the 
medicinal leech populations in wetlands around Lake Eğirdir are protected. Some biological, ecological, and operational factors are thought to be effective in this result. Long-term passive staying of medicinal leeches in bottom of habitats without any reaction after feeding period (Dickinson and Lent, 1984), the difficulties of leech collection due to habitat structure and decrease of the water level of the lake, and the collection on just only swimming leeches suggest that the collection pressure on leeches is not primary threat for medicinal leech populations.

The populations of $H$. medicinalis living in European wetlands have significantly declined (Elliott and Tullett, 1984; Elliott and Kutschera, 2011). The populations of $H$. verbana in the wetlands of the Black Sea Region (Turkey) where leech collection is the most intense in Turkey, also are declining day by day (Sağlam, 2011). However, the findings of the present study revealed that the populations of $H$. verbana living in the wetlands around Lake Eğirdir are protected. It is thought that stability in the withdrawal and rise of the water level of the lake, the variety and abundance of the host in the undamaged wetlands, the social structure of the leech collectors, the sales policies, and the effective activities of conservation and control units play important role on the protection of the ///medicinal leech populations living around Lake Eğirdir.

The marking methods (Wilkin and Scofield, 1991; Anonymous, 1997), Ekman dredge and modified unit square design methods (Sağlam et al., 2008) were used to estimate the medicinal leech population sizes. However, marking methods cause the injuries and deaths in leeches (Wilkin and Scofield, 1991). There are operational difficulties in using the Ekman dredge and modified unit square design methods due to habitat structure of the wetlands. It seems that the removal methods are more effective and leech-friendly compared to the other methods to estimate the population size of the medicinal leeches. Non-injury to the leeches, easy application, and taking quick results are the strengths of removal methods compared to other methods. However,

\section{REFERENCES}

Anonymous (1997). Determination of Hirudinea fauna, mainly medicinal leech in Turkey (Project report) (in Turkish). Ankara: Ministry of Environment General Directorate of Environmental Protection.

Ceylan, M. \& Erbatur, İ. (2012). A study on nutrition of medicinal leech (Hirudo verbana Carena, 1820): Cannibalism?. Ege Journal of Fisheries and Aquatic Sciences, 29(4), 167-170. DOI: 10.12714/egejfas.2012.29.4.03

Ceylan, M., Çetinkaya, O., Küçükkara, R. \& Akçimen, U. (2015). Reproduction efficiency of the medicinal leech Hirudo verbana Carena, 1820. Turkish Journal of Fisheries and Aquatic Sciences, 15, 411-418. DOI: 10.4194/1303-2712-v15_2_27

Ceylan, M. (2016). Determination of ecology, population size and catch efficiency of medicinal leech (Hirudo verbana Carena, 1820) populations in wetlands around Lake Eğirdir (PhD thesis) (in Turkish with English abstract). University of Süleyman Demirel, Turkey. removal methods are based on actively swimming leeches reacting to catch operations, the findings of the present study should be regarded as the catchable population size. The removal methods used in the present study, therefore, should be improved considering also inactive leeches.

This study revealed that both "Maximum Probability" and "Regression" methods used for the first time to estimate the population size of the medicinal leech, $H$. verbana can be applied reliably. In addition, the reliable results obtained from the Modal Progression Analysis (Bhattacharya's method), which was used for the first time in estimating the age classes for leeches (Hirudinea), may shape the future studies on medicinal leech populations. The methods regarding medicinal leech populations estimation used in the present study will serve to determine catch limits and export quotas in accordance with realistic and scientific norms needed to contribute to the monitoring and sustainable management of $H$. verbana populations, which have a significant share in the world's leech trade. Considering that the medicinal leech populations are declining day by day, and they are even completely extinct in many wetlands of Europe and Turkey, it is suggested that the wetlands around Lake Eğirdir should be regarded as model habitats in terms of conservation and sustainable management of medicinal leech populations. To contribute to the conservation of the medicinal leech $H$. verbana populations, the size of the medicinal leech populations should be determined at regular intervals and the annual leech collecting limits should be applied for each wetland, at least where commercial leech collection is conducted.

\section{ACKNOWLEDGEMENTS}

This study was supported by Süleyman Demirel University, Scientific Research Projects Coordination Unit (SDU-BAP 3341-D2-12). The authors are grateful to Eğirdir Fisheries Research Institute for laboratory support. We also thank Dr. Ramazan KÜÇÜKKARA and Ufuk AKÇiMEN for help in the laboratory.
Ceylan, M. \& Çetinkaya, O. (2017). Investigation on the collection and economy of medicinal leeches from wetlands around lake Eğirdir, Turkey (in Turkish with English abstract). Türkiye Parazitoloji Dergisi, 41(2), 96101. DOI: $10.5152 /$ tpd.2017.5150

Ceylan, M., Küçükkara, R. \& Akçimen, U. (2019). Effects of broodstock density on reproduction efficiency and survival of southern medicinal leech, Hirudo verbana Carena, 1820. Aquaculture, 498, 279-284. DOI: 10.1016/j.aquaculture.2018.08.016

Ceylan, M., Çetinkaya, O. \& Kvist, S. (2021a). Function of the waterfowl nests as reproduction and living areas for leeches (Annelida: Hirudinea). Animal Reproduction Science, 232, 106816.

DOI: 10.1016/j.anireprosci.2021.106816

Ceylan, M., Küçükkara, R., Erbatur, İ., Karataş, E., Tunç, M. \& Sağlam, N. (2021b). Growth, survival and reproduction of the Turkish medicinal leech, Hirudo sulukii. Invertebrate Reproduction \& Development, 6581(1), 57-68. DOI: 10.1080/07924259.2021.1885506 
CITES (2021). Convention on International Trade in Endangered Species of Wild Fauna and flora: Appendices I, II and III. Retrieved from https://cites.org/eng/app/appendices.php (16.07.2021).

Collier, K. J., Probert, P. K. \& Jeffries, M. (2016). Conservation of aquatic invertebrates: concerns, challenges and conundrums. Aquatic Conservation: Marine and Freshwater Ecosystems, 26(5), 817-837. DOI: $10.1002 /$ aqc. 2710

Demirsoy, A., Kasparek, M., Akbulut, A., Durmuş, Y., Akbulut (Emir), N. \& Çalışkan, M. (2001). Phenology of the medicinal leech, Hirudo medicinalis L., in north-western Turkey. Hydrobiologia, 462, 19-24. DOI: 10.1023/A:1013153804463

Dickinson, M. H. \& Lent, C. M. (1984). Feeding behavior of the medicinal leech, Hirudo medicinalis L. Journal of Comparative Physiology A, 154, 449-455. DOI: 10.1007/BF00610160

Elliott, J. M. \& Tullett, P. A. (1984). The status of the medicinal leech Hirudo medicinalis in Europe and especially in the British Isles. Biological Conservation, 29(1), 15-26. DOI: 10.1016/0006-3207(84)90011-9

Elliott, J. M. \& Tullett, P. A. (1986). The effects of temperature, atmospheric pressure and season on the swimming activity of the medicinal leech, Hirudo medicinalis (Hirudinea; Hirudinidae), in a Lake District Tarn. Freshwater Biology, 16(3), 405-415.

DOI: 10.1111/j.1365-2427.1986.tb00981.x

Elliott, J. M. (2008). Population size, weight distribution and food in a persistent population of the rare medicinal leech, Hirudo medicinalis. Freshwater Biology, 53(8), 1502-1512.

DOI: 10.1111/j.1365-2427.2008.01978.x

Elliott, J. M. \& Kutschera, U. (2011). Medicinal leeches: historical use, ecology, genetics and conservation. Freshwater Reviews, 4(1), 21-41. DOI: 10.1608/FRJ-4.1.417

Elliott, J. M. \& Dobson, M. (2015). Freshwater leeches of Britain and Ireland: keys to the Hirudinea and a review of their ecology. Freshwater Biological Association Scientific Publication.

Gayanilo, F. C., Sparre, P. \& Pauly, D. (2005). The FAO-ICLARM stock assessment tools II, User's guide. FAO Computerized Information Series Fisheries.

Kasparek, M. (1998). Leeches for export - A threatened species as a pharmaceutical raw material. Focus gate, 1/98, 22-25.

Kutschera, U. (2006). The infamous blood suckers from Lacus Verbanus. Lauterbornia, 56, 1-4.

Kutschera, U. \& Roth, M. (2006). Cocoon deposition and cluster formation in populations of the leech Hirudo verbana (Hirudinea: Hirudinidae). Lauterbornia, 56, 5-8.

Kutschera, U. \& Elliott, J. (2014). The European medicinal leech Hirudo medicinalis L.: morphology and occurrence of an endangered species. Zoosystematics and Evolution, 90(2), 271-280.

DOI: $10.3897 /$ zse. 90.8715

Leslie, P. H. \& Davis, D. H. S. (1939). An attempt to determine the absolute number of rats on a given area. The Journal of Animal Ecology, 8(1), 94-113. DOI: $10.2307 / 1255$

Neubert, E. \& Nesemann, H. (1999). Annelida, Clitellata: Branchiobdellida, Acanthobdellea, Hirudinea. Süßwasserfauna von Mitteleuropa 6/2 Spektrum Akademischer Verlag.

Official Gazette (2014). Regulation on allocation medicinal leech (Hirudo verbana) export quota of 2014. Retrieved from http://www.resmigazete.gov.tr/eskiler/2014/01/20140110-17.htm (16.07.2021).
Official Gazette (2020a). Regulation on allocation medicinal leech (Hirudo verbana) export quota of 2021. Retrieved from https://www.resmigazete.gov.tr/eskiler/2020/11/20201128-12.htm (16.07.2021).

Official Gazette (2020b). Notification No. 5/1 regulating commercial fisheries. Retrieved from https://www.resmigazete.gov.tr/eskiler/2020/08/20200822-8.pdf (16.07.2021).

Özdamar, K. (2011). Statistical data analysis with package program-1 (in Turkish). Eskişehir: Kaan Publishing House.

Petrauskienè, L., Utevska, O. \& Utevsky, S. (2009). Can different species of medicinal leeches (Hirudo spp.) interbreed?. Invertebrate Biology, 128(4), 324-331. DOI: 10.1111/j.1744-7410.2009.00180.x

Ricker W. E. (1975). Computation and interpretation of biological statistics of fish populations. Ottawa: The Blackburn Press.

Sağlam, N., Dorucu M., Ozdemir Y., Seker E. \& Sarieyyupoglu, M. (2008). Distribution and economic importance of medicinal leech, Hirudo medicinalis (Linnaeus, 1758) in Eastern Anatolia/Turkey. Lauterbornia, $65,105-118$.

Sağlam, N. (2011). Protection and sustainability, exportation of some species of medicinal leeches (Hirudo medicinalis L., 1758 and Hirudo verbana Carena, 1820) (in Turkish with English abstract). Journal of FisheriesSciences.com, 5(1), 1-15.

Sağlam, N., Saunders, R., Lang, S. A. \& Shain, D. H. (2016). A new species of Hirudo (Annelida: Hirudinidae): historical biogeography of Eurasian medicinal leeches. BMC Zoology, 1, 5 . DOI: $10.1186 / s 40850-016-0002-x$

Sağlam, N., Özbay, Ö., Demir, T., Balcı, M., Pala, A. \& Kıııç, A. (2018). Effect of water quality on monthly density variation of the endangered southern medicinal leech Hirudo verbana Carena, 1820 (Hirudinea: Arhynchobdellida: Hirudinidae). Acta Zoologica Bulgarica, 70(3), 433-441.

Sawyer, R. T. (1986). Leech Biology and Behavior, Vol: I, II, III. Oxford: Oxford University Press.

Shaffer, M. L. (1981). Minimum population sizes for species conservation. BioScience, 31(2), 131-134. DOI: 10.2307/1308256

Trontelj, P. \& Utevsky, S. Y. (2005). Celebrity with a neglected taxonomy: molecular systematics of the medicinal leech (genus Hirudo). Molecular Phylogenetics and Evolution, 34(3), 616-624.

DOI: 10.1016/j.ympev.2004.10.012

Trontelj, P. \& Utevsky, S. Y. (2012). Phylogeny and phylogeography of medicinal leeches (genus Hirudo): fast dispersal and shallow genetic structure. Molecular Phylogenetics and Evolution, 63(2), 475-485. DOI: 10.1016/j.ympev.2012.01.022

Uğural, B. \& Serezli, R. (2020). Effects of various environments on number of cocoon and offspring in breeding of southern medicinal leech, Hirudo verbana Carena, 1820. Ege Journal of Fisheries and Aquatic Sciences, 37(3), 207-211. DOI: 10.12714/egejfas.37.3.01

Wilkin, P. J. (1989). The medicinal leech, Hirudo medicinalis (L.) (Hirudinea: Gnathobdellae), at Dungeness, Kent. Botanical Journal of the Linnean Society, 101(1), 45-57. DOI: 10.1111/j.1095-8339.1989.tb00135.x

Wilkin, P. J. \& Scofield, A. M. (1991). The structure of a natural population of the medicinal leech, Hirudo medicinalis, at Dungeness, Kent. Freshwater Biology, 25(3), 539-546. DOI: 10.1111/j.1365-2427.1991.tb01397.x

Zippin, C. (1956). An evaluation of the removal method of estimating animal populations. Biometrics, 12(2), 163-189. DOI: 10.2307/3001759 